\title{
Public health surveillance, public communication and participation
}

\author{
Lesley V. D’Anglada
}

\section{CONTENTS}

$\begin{array}{ll}\text { Introduction } & 801\end{array}$

$\begin{array}{lll}15.1 & \text { Aspects of surveillance } & 803\end{array}$

15.2 Incident Response Plans for cyanobacterial blooms 804

15.3 Roles and capacities of the responsible authority $\begin{array}{ll}\text { in incidence responses } & 808\end{array}$

$\begin{array}{ll}15.4 \text { Monitoring } & 810\end{array}$

$\begin{array}{ll}\text { 15.5 Management and control measures } & 814\end{array}$

$\begin{array}{lll}15.6 & \text { Risk communication } & 816\end{array}$

15.6.1 Communication preparedness before blooms occur $\quad 817$

15.6.2 Communication during a cyanotoxin incident $\quad 819$

15.6.3 Communication after a cyanotoxin incident $\quad 819$

$\begin{array}{lll}15.7 & \text { Follow-up assessment of incident management } & 820\end{array}$

$\begin{array}{ll}15.8 \text { Public participation } & 820\end{array}$

$\begin{array}{lr}\text { Further Reading } & 827\end{array}$

\section{INTRODUCTION}

The role of public health authorities is to protect, assess and ensure the health of people and communities. These agencies also play a role in promoting healthy environments, thus reducing the toll from illness due to exposure to pathogens or harmful substances such as cyanotoxins in drinking and recreational waters, in food or in water used for dialysis. Legal authority and regulations facilitate the control and management of blooms as well as public health responses and risk communication when they do occur.

The role of the responsible authority is likely to focus on surveillance, including independent verification of water quality and ideally, assessment that Water Safety Plans (WSPs) are being implemented effectively, rather than the day-to-day on-site management and monitoring. Operators of drinkingwater supplies and managers of recreational sites or occupational water use are required for the day-to-day management (and assessment) of risks, including those from cyanotoxins. However, the role of authorities may be broader 
where regulations are sparse, water quality requirements such as limits for cyanotoxin concentrations have not been defined, institutional capacity is limited or the surveillance of water-use systems is challenging because of their high number, geographic spread or remoteness. Such situations may require an active role of public authorities in management, for example, in the development of WSPs (see Chapter 6). This chapter focuses on the role of public authorities in surveillance, the development and implementation of Incident Response Plans (IRPs) as well as in communicating risks to the public.

The WHO Framework for safe drinking-water outlines the key steps in providing safe drinking-water (Figure 15.1; see also the Guidelines for Drinking-Water Quality (WHO, 2017), Chapter 1), and these key steps can also be applied to safe design, operation and management of recreational or occupational water-use sites. Within this framework, public authorities have a role particularly at the "front end", that is, in setting targets, and at the "back end", that is, in surveillance. The authorities responsible for both may be different, operating on different levels: while setting targets often occurs on the national level by legislation, surveillance is typically local, requiring good knowledge of the local conditions and challenges.

Setting cyanotoxin water quality targets or action thresholds can be based on the guideline values summarised in Chapter 5 (see also Chapter 2 for their derivation), with the guideline values for short-term exposure through drinking-water being particularly relevant during bloom events. How the guideline values for lifetime exposure "translate" into targets for waterbody management is discussed in Chapters 6 and 7. In an event of a cyanotoxins incident, it is important to consider the risks from exposure to cyanotoxins

FRAMEWORK FOR SAFE DRINKING-WATER

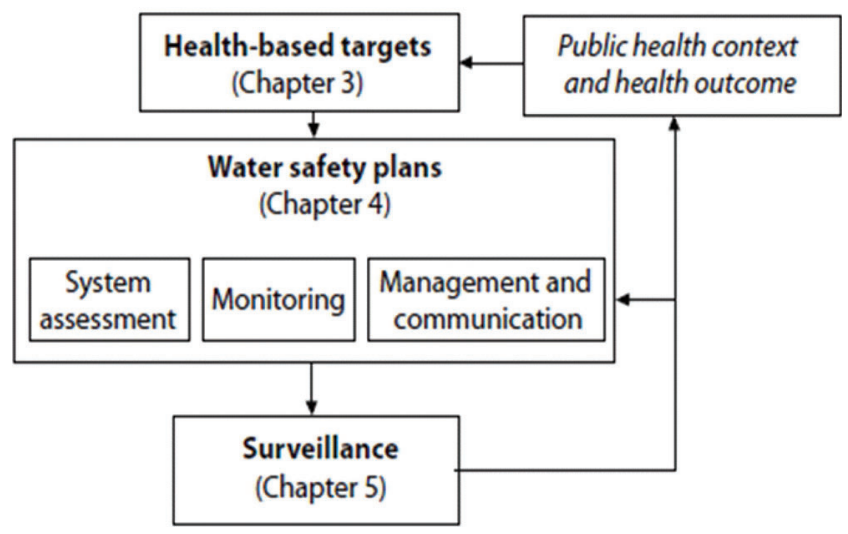

Figure 15.I Framework for safe drinking-water (from the WHO Guidelines for Drinkingwater Quality; WHO, 2017). 
in relation to health risks from other microorganisms and chemicals (see section 5.1 and Chapter 6 for a discussion on target setting).

\section{I5.I ASPECTS OF SURVEILLANCE}

The other key role of public authorities, that is, surveillance, is often perceived to focus on assessing whether water quality meets the targets defined for a given parameter, such as cyanobacterial biomass or cyanotoxin concentrations. However, for drinking-water supply, surveillance is much more effective if it also includes a critical review of the facilities, their surroundings and operation, including operational parameters. This is best done through inspections of the site, review of records of operational parameters and conversations with operating staff. If management plans such as WSPs (see Chapter 6) and IRPs (see below) are in place, this greatly facilitates surveillance and provides a useful basis for discussions on potential improvement with operators and managers. This also applies to small supplies and situations with limited resources, where WSP development can be particularly useful (for more information, see WHO, 2012). As small supplies are typically less complex, system description, hazard analysis and risk assessment tend to be more straightforward and more readily accomplished even with a lower level of expertise, for example, by using a sanitary inspection as basis for the WSP. Outcomes may be highly valuable, allowing the water authority to prioritise its activities. For drinking-water supplies as well as for recreational sites or workplaces, surveillance should start with site inspections to assess the risk of cyanobacterial blooms, based on historical events and environmental conditions that lead to cyanobacterial bloom formation. Surveillance therefore requires an understanding of the systems - from catchment to the point of use and possible human exposure. The guidance given in Chapters 5-10 presents the necessary background, both for operators and for authorities performing surveillance, on assessing and managing risks of cyanobacterial blooms.

Through surveillance, public authorities gather a wide overview of conditions causing blooms and thus develop a locally and regionally specific understanding of the water systems. This enables them to effectively advise operators of drinking-water supplies and managers of recreational sites or workplaces on measures that have proven effective in similar cases. The operator of a drinking-water supply or manager of a recreational site is responsible for identifying hazards, assessing risks and identifying as well as implementing control measures, including organising collaboration with other public authorities and agencies. However, particularly in small-scale situations with limited resources, the role of public authorities can also involve triggering networking and exchange of experience between operators as well as organising collaboration. 
Across the globe, different authorities may be responsible for responding to cyanotoxin occurrence, and responsibility may also be shared between environmental and health authorities. For managing cyanobacteria and cyanotoxins, contact and exchange are particularly important between health and environmental authorities, but in some cases also with those responsible for allocating water to specific uses and managing flow regimes (in some countries termed "water boards"). This is a basis for developing management strategies that address the problem at its source: that is, the causes for cyanobacterial proliferation and bloom formation.

To ensure appropriate responses to cyanobacterial bloom incidents, close coordination with all partners, including environmental authorities, is particularly critical so that those with responsibilities for specific incidence response actions are prepared to react quickly when contacted during the incident, to restore drinking-water service. IRPs help in providing the tools needed for an effective response and the protection of public health during a cyanobacterial bloom. Each cyanotoxin event is different, and correspondingly, the characteristics of the area, available resources, the interaction with outside partners and the response will be specific to the situation.

\section{I5.2 INCIDENT RESPONSE PLANS FOR CYANOBACTERIAL BLOOMS}

The assessment of water-use systems according to Chapters 6-8 will show whether conditions are likely to support cyanobacterial dominance or blooms and whether they should be expected in surface waters used for drinking-water supplies, recreational or occupational use, particularly where there is a previous history of blooms. This can occur even when management measures to reduce their likelihood have recently been implemented because these measures usually require several years to start having an effect. In mildly eutrophic waterbodies, cyanobacterial dominance may occur only occasionally and as short-lived events, thus being perceived as an unusual incident. In more heavily eutrophic waterbodies, they may be a regular phenomenon throughout several months of the year, to which regular management actions such as drinking-water treatment or periodic warnings regarding recreational use have been adapted. Nonetheless, even in such settings, particularly dense blooms may constitute an "incident". Depending on the local conditions, Incident Response Plans (IRPs) will describe the actions and responses to be applied within a water-use system when events, such as a cyanobacterial bloom is not sufficiently controlled by normal operating procedures, occur. IRPs are typically developed by site operators or waterbody managers but approved by the public health authority. However, recreationally used waterbodies and beaches may not be formally managed or operated, and the responsibility for their monitoring may 
lie with the health authority which then also is responsible for coordinating the implementation of the IRP.

IRPs include incident criteria, roles and responsibilities, communication protocols, contact information of responsible authorities to involve in the response, mechanisms for monitoring and controlling the bloom and, where appropriate, the communication to the public: both about the risk and about actions to take to avoid exposure. It may be useful to prepare templates that site operators can adapt depending on the situation and the available resources (see Tables 15.1-15.3 for examples). Sections 15.3-15.5 outline the three important steps for the responsible authority to follow in response to cyanotoxin bloom incidents in drinking-water and water to which people are exposed during occupational or recreational use. These steps include monitoring, management to control the incident and risk communication. The Alert Levels Frameworks (ALFs) for drinking-water supplies (section 5.1) and for recreational waterbody use (section 5.2) give criteria for identifying an incident (i.e., Alert Level 2), provide a structure for responses to monitoring results that can be used directly when developing the IRP or adapted to local circumstances, as needed.

Table 15. I Incident response and/or risk communication task force contacts

\begin{tabular}{|c|c|c|c|c|c|}
\hline \multicolumn{6}{|c|}{ Principal Authority: } \\
\hline \multirow[t]{3}{*}{ Name } & Title & $\begin{array}{l}\text { Incident } \\
\text { Role }\end{array}$ & Phone & E-mail & Address \\
\hline & & & $\begin{array}{l}\text { Office: } \\
\text { Mobile: }\end{array}$ & & \\
\hline & & & $\begin{array}{l}\text { Office: } \\
\text { Mobile: }\end{array}$ & & \\
\hline \multicolumn{6}{|c|}{ Partner Authority: } \\
\hline \multirow[t]{3}{*}{ Name } & Title & $\begin{array}{l}\text { Incident } \\
\text { Role }\end{array}$ & Phone & E-mail & Address \\
\hline & & & $\begin{array}{l}\text { Office: } \\
\text { Mobile: }\end{array}$ & & \\
\hline & & & $\begin{array}{l}\text { Office: } \\
\text { Mobile: }\end{array}$ & & \\
\hline
\end{tabular}

Partner Authority:

Name Title $\begin{gathered}\text { Incident } \\ \text { Role }\end{gathered}$ Phone E-mail Address

(Cont.)

Authority: e.g., Drinking-Water Supplier, Ministry of Health and its regional or departmental offices, Environmental Protection, Health Departments, Local Governments, Emergency Management, Environmental (or) Public Health Laboratories, etc.

Title: Drinking-water supplier, water treatment operator, recreational site manager, engineer, water quality officer, etc. 
Table 15.2 Checklist of resources and capabilities for responses to a cyanobacterial incident

_ Roles and contact details for key personnel and other related partners are clearly stated;

_ Trigger levels for action to take during cyanobacterial biomass (in terms of biovolume or of chlorophyll-a) and cyanotoxins, including Alert Levels Framework (ALF), are established;

\section{Monitoring}

_ Appropriate personnel to perform

$$
\text { _ Monitoring/Sampling _ Laboratory analysis }
$$

is identified and contacts are documented;

_ Appropriate monitoring and sampling procedures have been established;

_ Appropriate public health laboratories to conduct sample analysis are identified;

_ Appropriate SOPs and QA/QC protocols have been established;

_ Monitoring and sampling records templates have been developed;

_ Required equipment and materials are available and their storage site is described in the incident response plan for

_ Monitoring/sampling _ Laboratory analysis

\section{Management and Control}

Appropriate personnel to perform the control/mitigation and treatment techniques is identified and contacts are documented;

_ Clear description of the actions required in the event of a cyanotoxins incident in

_ Drinking-water _ Recreational sites

have been developed and are described in the IRP;

_ Appropriate mitigation/control measures for blooms in surface waters have been identified and are available;

_ Appropriate treatment techniques for the removal of cyanotoxins in drinkingwater have been identified and are available;

_ Plans for alternative water supply including how to obtain, transport and distribute the alternate sources are available;

_ Templates to record the mitigation/control and treatment techniques have been developed;

\section{Risk Communication}

_ Appropriate personnel to perform risk communication is identified and prepared;

_A risk communication plan with a list of contacts, communication steps and dissemination outlets is available;

_ Checklists, templates, $\mathrm{Q}$ and $\mathrm{A}$, fact sheets and other reference materials including technical information (e.g., explanation of ALF) have been prepared and are up to date;

_A post-incident comprehensive assessment is available. 
Table 15.3 Post-cyanobacterial incident-response assessment checklist

Date of Assessment: Date and Location of Incident:

Incident-Response Responsible Agency:

Responsible Point of Contact Information:

Assessment Committee or Task Force Members:

For each of the areas below, please check the factors that met the requirements of a successful response. In the Comments section, identify and describe those that require improvement.

\section{Monitoring}

_ Availability and skill level of personnel in charge of _ Monitoring/Sampling

_ Laboratory analysis

_ Appropriate monitoring and sampling procedures

_ Timely contact and services with public health laboratories to conduct sample analysis

_ Availability of clear and effective SOPs and QA/QC protocols

_ Availability of clear monitoring and sampling records and templates available

_ Availability and functionality of required equipment and materials

_ Monitoring/Sampling

— Laboratory analysis

Comments:

\section{Management and Control}

Personnel in charge of control/mitigation and treatment techniques were available and skilled;

_ Description of the required steps to follow for incidents for:

_ Drinking-water _ Recreational sites

_ Mitigation/control measures for blooms in surface waters were available and effective;

_ Treatment techniques for the removal of cyanotoxins in drinking-water were available and effective;

_ The transportation and distribution of alternative water supply were effective;

_ Mitigation/control and treatment techniques records forms were appropriate;

Comments: 
Table 15.3 (Continued) Post-cyanobacterial incident-response assessment checklist

\section{Risk Communication}

Personnel in charge of the Risk Communication were available and skilled;

- The risk communication plan (list of contacts, communication steps and dissemination) was appropriate;

The checklists, templates, questions and answers, fact sheets and other reference materials including technical information (e.g., explanation of ALF) were appropriate and up to date;

_ Responses in the media met expectations;

_ New communication problems arose.

Comments:

\section{Additional Discussion Questions:}

I. What actions were successful that should be replicated in future incidents?

2. What actions did not work as planned? Why?

3. List any procedures, templates, checklists or communication materials that need revision.

4. Please list the remediation actions and who will be involved in doing them.

5. Who will inform the responsible agency and partner authority/agencies of the improvements and changes?

6. What is the time frame for making the revisions and informing others?

7.

8.

\section{I5.3 ROLES AND CAPACITIES OF THE RESPONSIBLE AUTHORITY IN INCIDENCE RESPONSES}

Convening a multiagency and multidisciplinary committee, or task force, is essential for an effective and rapid surveillance and response to a cyanotoxin bloom. The IRP therefore should clearly define the responsible personnel, including roles, responsibilities and legal liabilities (Table 15.1). These contacts listed in the IRP are also responsible for coordinating with further partners who might be involved during the cyanotoxin incident. Stakeholders to consider to include in the IRP for further involvement, with clear roles and responsibilities, may include the ministry of health (or public health) and its regional or departmental offices, environmental protection authorities, health departments, local governments, emergency management agencies, medical and veterinary personnel, water suppliers, drinking-water consumers, recreational site operators and users, and the public. Other potential response partners include neighbouring environmental and/ 
or public health laboratories, other drinking-water utilities and the media. The roles outlined in the IRP should provide a description of the tasks for which each should be prepared and what is expected from the other agencies and supporting partners before, during and after the bloom. Their roles should be outlined clearly and regularly updated, together with contact information. The contact information should include the names, titles, addresses and all applicable phone numbers, as well as a secondary contact in case the primary contact cannot be reached.

The responsible authorities should also identify the resources, infrastructure and staff (Table 15.2) to effectively respond to the cyanotoxin incident. Available resources include necessary tools and equipment (e.g., sampling equipment) and laboratories that may be approached if needed. Drinkingwater providers should determine their type of intakes and depths and establish if they are able to draw raw water from a different intake and/ or depth, with approval from the drinking-water regulator, as appropriate. They also should be aware of treatment adjustments that are beneficial as well as those that may exacerbate problems: for example, inducing lysis when water with cyanobacterial cells is subjected to certain treatment steps (see Chapter 10). For recreational use of eutrophic waterbodies which often harbour some cyanobacteria but only sometimes develop blooms reaching Alert Level 2 (see section 5.2), it will be important to give renewed information to site users, emphasising the use restrictions that now apply under Alert Level 2 but were not yet in place under Alert Level 1. Where comprehensive monitoring of sites used for recreation is not possible due to their very large number or due to limited resources, an option may be to include volunteer citizens in observing and reporting blooms ("scum scouting"). Monitoring may also include tools already developed by partners such as satellite imagery, bulletins, systems for notifying other agencies and monitoring programmes (see below) that may be ongoing for other purposes, such as monitoring for parameters other than cyanobacteria.

Incident planning requires not only a list of the communication and public outreach mechanisms, such as websites, e-mail alerts and social media channels, but also convening a committee or task force with the staff responsible for coordinating public communication to ensure that conflicting information is avoided. The responsible authorities should have also confirmed that the staff involved in the response have the necessary skills to conduct monitoring and are capable of effective risk communication. It is further useful for such staff to understand the conditions leading to blooms (described in Chapters 4 and 8) in order to better anticipate bloom events and tailor intensified surveillance to such periods.

A specific aspect of incidence response is the occurrence of suspected cases of illness linked to cyanobacterial occurrence. As discussed in sections 5.1 and 5.2, the limitation with many of the published cases suspected to have been caused by cyanobacteria is the lack of data on cyanotoxin concentrations in the water to which people were exposed to. If samples were taken 
at all, this usually occurred days later. It is therefore useful for Incidence Response Plans to include contacts of medical services and requirements to report the incident to them for two reasons: to keep them informed about heavy blooms and possible human exposure, and to ensure that they inform those who can initiate immediate sampling if cases of illness due to cyanobacteria are suspected. Criteria for concluding a likely link between cyanotoxins and the illness include that the symptoms are typical for the respective cyanotoxin and that concentrations were in a range possibly causing them. In the United States of America, the Center for Disease Control developed a voluntary reporting system called One Health Harmful Algal Bloom System $(O H H A B S)$ to collect data on individual human and animal cases of illnesses from $\mathrm{HAB}$-associated exposures, as well as environmental data, to support the understanding and prevention of HABs and HAB-associated illnesses. This reporting system is available to public health departments and their designated environmental health partners to help them better understand and identify the effects of cyanobacteria on humans, animals and the environment. Unspecific symptoms may be caused by other aetiological agents (including pathogenic microorganisms) that may or may not be associated with the bloom, or other unknown substances in cyanobacteria.

\section{I5.4 MONITORING}

Where the responsible authority is involved in surveillance monitoring, it may already be positioned to include cyanobacteria or even cyanotoxins. However, many countries do not include cyanobacteria or cyanotoxins in regular surveillance, or have limited resources to conduct monitoring. In cases with limited resources, collaboration with expert support and/ or creating partnerships at the regional or international level is useful for guidance on surveillance alternatives. As discussed in Chapter 11, an effective way forward may also be to create regional centres of excellence that can perform periodic cyanotoxin analyses on smaller numbers of selected samples that serve for orientation regarding the ratios of toxins to biomass or cell counts that then can be used locally for the bulk of samples. This is particularly useful where access to a chemical laboratory is missing or limited but microscopy is available for determining cell counts and biovolumes. Furthermore, seeking collaboration with research institutions can be very effective since they may have valuable expertise and analytical capacities. The example given in Box 15.1 illustrates how such collaboration can enable a low-cost approach to monitoring beaches. It is important that the Incident Response Plan (IRP) include contacts to laboratories that can analyse for cyanobacteria/toxins, and that agreements are in place for rapid reaction should a bloom occur that requires a rapid assessment. 


\section{BOX 15.I: THE EXPERIENCE OF URUGUAY WITH CYANOTOXIN RISK COMMUNICATION AND MANAGEMENT}

\section{Beatriz Brena}

The Rio de la Plata, located between Argentina and Uruguay, is a broad, funnel-shaped estuary that drains the waters of two important rivers (Parana and Uruguay) into the Atlantic Ocean. With a basin of 3.2 million $\mathrm{km}^{2}$, the second largest in South America after the Amazon, it has about 150 million inhabitants (35\% of South America) and more than 75 big reservoirs for hydroelectric power generation. The main regional economic activities are agriculture and livestock production.

In the past 20 years, intense cyanobacterial blooms became frequent especially in the main reservoirs of the basin and reached Montevideo, the capital of Uruguay, a city with I.3 million inhabitants located in the middle of the Rio de la Plata in the salinity and turbidity front of the estuary. The blooms had a great impact in the quality of life of people, since the estuary has a long coast of sandy beaches intensively used for recreation of both locals and tourists. Eutrophication could be associated with an intensification of agriculture; for example, the use of fertilisers increased more than threefold between 2000 and 2010 .

The predominant cyanobacteria being Microcystis, mostly M. aeruginosa, considering its potential production of toxins, in the year 2000, the City Government implemented regular beach and coastal water monitoring. This included visual detection of blooms as well as analyses of chlorophyll- $a$ and nutrients. The visual monitoring approach, performed at the beach, was based on a simple categorisation of samples in three groups: (i) "absence" of blooms when the operator does not detect any cyanobacterial colony by visual inspection and there are no signs of water discoloration; (ii) "presence of dispersed colonies" when colonies are observed from a close distance, for example, when entering into the water; and (iii) "scums", when the accumulation of colonies produces green colour like spilled paint, noticeable from several metres from the shore.

At the beginning, there was no public awareness of the risks associated with these blooms; they were mostly perceived as an aesthetic problem. The first scientific report of the presence of microcystins in the Rio de la Plata was in 200I, and the analysis was performed in Brazil, since no analytical capacity for cyanotoxins was installed in Uruguay. A collaboration with the University of the Republic of Uruguay was then established, starting in the summer of 2004, for the development and validation of an ELISA for microcystins, which was then 
included in the regular monitoring of beach water. The results demonstrated extremely high microcystin concentrations in the scums (up to $30000 \mu \mathrm{g} / \mathrm{L}$ ) and prompted the notification to the public to prevent recreational exposure.

The data accumulated over the first 6 years of monitoring showed that more than $95 \%$ of the scums were very toxic (mean $3300 \mu \mathrm{g} / \mathrm{L}$ ), while microcystin concentrations in most of the samples in the "presence of dispersed colonies" were very low $(<0.3 \mu \mathrm{g} / \mathrm{L})$; however, even in this intermediate category $5.6 \%$ of the samples contained more than $20 \mu \mathrm{g} / \mathrm{L}$. Noteworthy, when no blooms were detected (category "absence"), microcystin concentrations in the samples were below or equal to $0.3 \mu \mathrm{g} / \mathrm{L}$.

These data serve to support the risk management approach, based on visual observation and a simple and fast method for microcystin determination. Since the antibodies and specific reagents of the ELISA kit were developed locally, the cost of analysis was very low and the approach is sustainable.

As Montevideo is in the salinity and turbidity front of the estuary, the intensity and frequency of the blooms is very variable and depends mainly on the inflow of water from the major rivers Paraná and Uruguay. An increase in the freshwater discharge due to rainfall in the upper basin is associated with the upcoming of blooms, originating upstream in the major reservoirs. In the summer of 2010, under the effect of "El Niño", scums in the coastal waters of Montevideo were very frequent (blooms occurred about $40 \%$ of the time along parts of the coast). Improving public communication and emphasising the need to prevent exposure was therefore indispensable. Recreational use of the beaches is a major activity in summers, but unfortunately, many people disregard the warning messages.

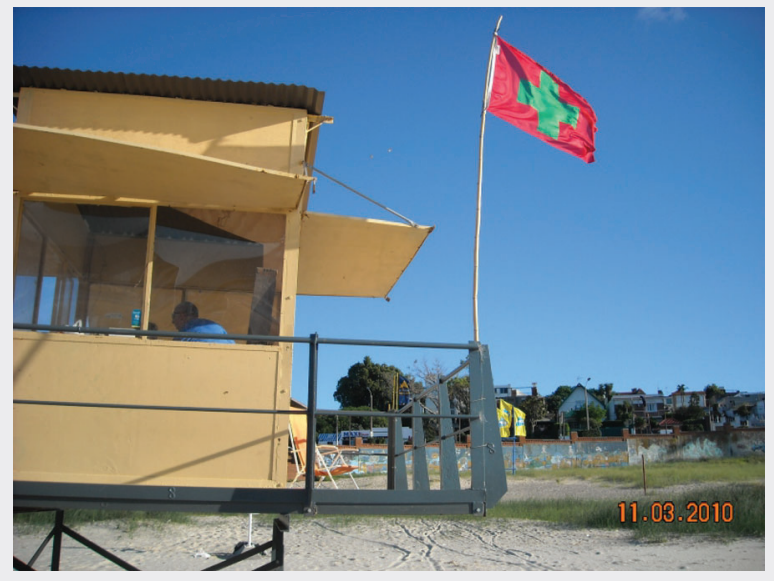


In consequence, a so-called sanitary flag (red flag with a green cross in the middle; see photo) was implemented. An intensive campaign in the public media explained its meaning and relevance. Furthermore, as the blooms can be highly dynamic, particularly in Montevideo where they can appear and disappear very rapidly, for example, within I h or even less, depending on the beach, lifeguards were trained to recognise the presence of blooms. Thus, a rapid on-site response was made possible at each beach at any moment during the course of a day, if necessary. Even so, in 2015, there was a report of a serious intoxication, most likely attributable to ingestion of bloom material (see section 5.2), of a 20-month-old girl who required a liver transplant. This means that there is still a lot to learn to prevent intoxication and to promote proper care of children and sensitive populations. At present, the National Environmental Direction generalised the use of the sanitary flag countrywide, and the information of beaches with a sanitary flag is published daily on the web so that the population can decide whether it is safe to go to the beach.

A further aspect of preparing for monitoring in the context of incident response is to clarify which threshold concentrations of cyanobacterial biomass (measured as biovolume, chlorophyll- $a$ or other parameters chosen locally; see the Alert Level Frameworks (ALFs) in sections 5.1 and 5.2) or of cyanotoxins are to trigger which responses. This requires identifying whether regulations and/or guidance for cyanobacteria or cyanotoxins are in place, particularly for drinking-water, and if so, to include the respective statutory and regulatory requirements when developing the IRP. Where these are lacking, the drinking-water guidance values as well as the guidance values for recreational exposure, in Chapter 2 of this book, serve for orientation. Furthermore, the ALFs given for drinking-water in section 5.1 and for recreational or occupational exposure in section 5.2 highlight the sequence of events to follow for monitoring and management. The Alert Level values are intended for managers of water supplies, recreational or occupational sites and may be used both for normal day-to-day operations and for situations in which blooms escalate to be an incident that requires a quick response. When developing the IRP, the ALF templates given here are best adapted to the locally specific conditions, including availability of analytical capacity for determining concentrations of cyanobacterial biomass and/ or cyanotoxins.

Monitoring may be tailored not only for verification of whether water quality targets or action thresholds for cyanobacteria or cyanotoxins are met, but also to assess whether the implemented control measures are 
achieving the desired objectives. Both for surveillance monitoring and for the IRP, it is important that operators as well as authorities develop and implement sampling procedures, sample analysis processes, and quality control and assurance plans (see Chapters 11-14). This involves coordination with the respective internal and/or external laboratories regarding sampling procedures, preservation, shipment and laboratory requirements. Documentation from the laboratory conducting the analyses should also be kept, including number of samples, a description of analytical methods, sampling, sample transport and analytical quality assurance procedures, and the results.

It is further worthwhile to consider partnering with others (e.g., citizens' monitoring programmes) for further support in monitoring. For example, swimmers and other users can contact local authorities if they see cyanobacterial scums, and householders can report unusual odours in their drinking-water supply. In the United States of America, communitybased "Water-Watch" or "Stream-Watch" monitoring programmes undertaken by high school students and community groups have been initiated to monitor and report the presence of cyanobacterial blooms (see US EPA Citizen Science Projects for more information; https://www.epa.gov/citizenscience). In Argentina, a citizen science project "Why are our reservoirs green?" (abbreviated CIANOBs) involves school children in reporting blooms (see Box 15.3).

Monitoring data should be recorded and maintained. Monitoring procedures should be reviewed regularly and tailored to the current conditions of the surface water and/or treatment plant, including consideration of the available resources. This can be an effective component of the periodic review of a Water Safety Plan (WSP).

If monitoring results indicate the presence of cyanotoxins in the surface water, further monitoring may be needed. Monitoring frequency as well as communication procedures will vary depending on the ALF and other factors such as the cost of monitoring and available resources.

\subsection{MANAGEMENT AND CONTROL MEASURES}

If cyanotoxins or substantial amounts of cyanobacteria are detected, the responsible authority should work together with operators of drinkingwater supplies and managers of recreational sites, as appropriate, and with health and cyanobacteria specialist or experts as well as public health laboratories to determine whether immediate or short-term responses are needed and which longer-term measures are appropriate. Many largerscale operations, that is, drinking-water supplies, recreational sites or 
workplaces, are responsible for day-to-day operations, including monitoring and incidence response planning as well as the notification of exceedances and the proposed response to the public surveillance authority. In such operations, the role of the public authority is to assess and approve the IRP proposed by the operators as well as to facilitate and support its implementation. However, in smaller-scale operations, a more active, coordinating role of the health authority may be necessary to fulfil these responsibilities.

Consultation with key technical (e.g., scientific and engineering) experts will help in both assessing the risk based both on the information about the waterbody (Chapter 9) and on the available laboratory data as well as in determining the locally appropriate control measures. These measures may encompass interventions taking immediate effect, particularly in drinkingwater treatment (Chapter 10), shifting water use to sites less prone to scum accumulation (Chapter 8 ) or restricting recreational use (section 5.2 and the ALF in Figure 5.4). However, a bloom incident should also trigger planning measures for prevention of blooms in future, using the momentum of expertise and experience with the waterbody that has already come together for the immediate response. Measures addressing the cause of blooms typically take longer to take effect, for example, controlling nutrient loads from the catchment (Chapter 7) or managing hydrophysical or food-chain conditions in the waterbody (Chapter 8). Some control measures (e.g., shifting recreational sites, applying algaecides or artificial mixing) may be subject to specific requirements or regulations, thus requiring consultation with the respective regulatory body that may need to issue a permit for conducting the measure.

Where immediate or short-term actions cannot be taken, or when shortterm water quality targets or action thresholds for toxins are exceeded (or bloom biomass indicates this potential), a temporary switch to an alternative drinking-water supply may be appropriate. Where resources are lacking for upgrading drinking-water treatment during blooms and bloom incidents occur regularly, the incident response plan (IRP) should include the identification, if feasible, of potential alternative water supplies. This may include plans for transporting clean, treated water from other areas or deploying portable water treatment systems, if available. Special precautions (e.g., portable water treatment systems or transported safe water supplies) may be advisable for "at-risk" groups especially susceptible to cyanotoxins, such as bottle-fed infants, small children and patients with previous acute liver and kidney damage (preferably identified in the course of developing a WSP; see Chapter 6). Boil water advisories are not recommended as boiling water will not remove the cyanotoxins. Other options are providing water in tanks or bottles to the affected population. This also 
requires specific planning when preparing an IRP, including pathways for providing information on distribution locations for bottled water to the affected communities.

When selecting a treatment or other control measure, the responsible operators or authority should consider any regulatory restrictions (such as mentioned above, e.g., for algicide application), specific characteristics of the waterbody, human resources, effectiveness, adverse impacts, short-term versus long-term results and costs versus benefits.

Once the situation is under control, sampling and monitoring is best continued as long as the bloom occurs in the waterbody in order to confirm that the measures taken are effective. The results of laboratory analyses provide a sound basis upon which the responsible authority can determine whether the cyanotoxins are now effectively under control and the water system can be returned to normal operations.

\section{I5.6 RISK COMMUNICATION}

The Incidence Response Plan should include the communication steps to follow when cyanobacteria and related toxin incidents occur, including the personnel responsible for initiating the communication, the order in which the notification should occur and the different communication methods to be used. Furthermore, information to the public needs to be given in formats that the respective public can read and understand. This may include tailoring to specific populations speaking different languages dialects, as well as knowledge and literacy levels. It may be useful to engage with knowledgeable regional partners to develop and or customise appropriate communication messages and materials. It may also be important to consider information formats for people with hearing and/or vision impairments as well as for persons with specific medical needs (such as people who are on dialysis) and for specific stages of life that may make people particularly sensitive to cyanotoxins such as pregnant and nursing mothers and those taking care of babies and young children.

Risk communication materials (see the Additional Tools and Resources for the Development of an Incident Response Plan in Box 15.2) with core messages can be customised for different countries and groups during different phases of the risk communication steps to ensure that drinking-water consumers, those using recreational sites or people potentially exposed at their workplace will obtain the information they need to protect themselves from cyanobacteria and cyanotoxins. 


\section{BOX 15.2: ADDITIONAL TOOLS AND RESOURCES FOR THE DEVELOPMENT OF AN INCIDENT RESPONSE PLAN}

\begin{tabular}{|l|}
\hline Tool or Resource Link (last accessed on 3 February 2020) \\
\hline Monitoring and Responding to Cyanobacteria and Cyanotoxins, USEPA \\
https://www.epa.gov/ground-water-and-drinking-water/ \\
cyanotoxin-management-plan-template-and-example-plans-0 \\
\hline Drinking Water Cyanotoxin Risk Communication Toolbox, USEPA \\
https://www.epa.gov/ground-water-and-drinking-water/ \\
drinking-water-cyanotoxin-risk-communication-toolbox-templates \\
\hline Recommendations for Public Water Systems to Manage Cyanotoxins in \\
Drinking Water, USEPA \\
https://www.epa.gov/ground-water-and-drinking-water/ \\
recommendations-public-water-systems-manage-cyanotoxins-drinking \\
\hline Drinking Water Advisory Communication Toolbox, CDC \\
https://www.cdc.gov/healthywater/emergency/dwa-comm-toolbox/index.html \\
\hline Guidelines for Safe Recreational Waters Volume I - Coastal and Fresh Waters, \\
WHO \\
https://apps.who.int/iris/handle/I0665/4259I \\
\hline International Guidance Manual for the Management of Toxic Cyanobacteria: \\
A Guide for Water Utilities,Australia \\
https://www.waterra.com.au/cyanobacteria-manual/PDF/ \\
GWRCGuidanceManualLevell.pdf \\
\hline
\end{tabular}

An important basis for promoting information that is clear and consistent is to convene a multiagency and multidisciplinary committee or task force across all responsible parties (as mentioned in section 15.2), that is, including drinking-water suppliers or recreational sites managers, communities and public health authorities as well as environmental and water quality regulators, before, during and after a cyanotoxin incident.

\subsection{Communication preparedness before blooms occur}

The responsible authority for managing the incidence response may vary depending on whether drinking-water, recreational water use or water use at workplaces is primarily affected. Particularly where multiple routes of exposure may be relevant, it is, however, important to clarify which authority will take the lead under which circumstances. Each authority potentially involved should determine the designated personnel to be part of the committee or task force responsible for developing the communication materials 
and for issuing the appropriate information. This includes determining the responsible person to lead the committee or task force in case the respective authority is to take the lead. The person in charge of the communications may be the one regularly in charge of the authority's public communication.

The committee or task force should develop a list of contacts within each authority potentially involved as well as the incident-related partners. The partners relevant for the bloom incident may include consumers, media, visitor centres, recreational parks and veterinarians - that is, representatives of those affected as well as of those to involve in the incident response. It is also important to include experts on cyanobacteria and cyanotoxins for two reasons: one is to gain their support for understanding potential health impacts and exposure routes as well as for determining the most effective control measures and appropriate actions. The other, which is sometimes challenging, is to integrate them in joint communication to the public in order to avoid disparities between the messages given.

If toxins occur at public health concerns levels (i.e., Alert Level 2 in the Alert Level Frameworks given in sections 5.1 and 5.2), the committee or task force will immediately need to ensure that information reaches critical partners such as dialysis and health care centres, childcare and critical care facilities, hospital and clinics, nursing homes, schools, food and beverages businesses and, if waterbodies affected are used for recreation, managers of sites such as lake shore recreational areas, visitor centres and recreational parks. This includes both the operators of such facilities and the consumers or people potentially affected, as listed above. Because of the diversity of those affected, different methods and pathways of communication will be effective for the respective audience. It is therefore effective to develop a contact list and/or decision tree similar to Table 15.1 with the responsible personnel that will be in charge of the communications, and this should include the contact information and the communication steps.

Generic communication materials are best developed prior to any bloom incident to guide drinking-water suppliers and managers of recreational sites to communicate to the public as appropriate (e.g., use of alternative water supply, do not drink advisory, recreational site closure) and kept updated in such a way that they can be readily adapted to any specific situation. The communication materials to consider developing include templates, news releases, beach postings, frequent questions and answers, fact sheets and other background materials. Pathways for distribution should also be identified, considering multiple outlets or media of communication to reach the greatest number of people in a timely manner. This could include media releases and briefings, e-mail and text message alerts, broadcasting, mass distribution through social media via Facebook, Instagram, Twitter, texts, others, posting on beaches and on websites, listservs by e-mail, phone messages, fliers, community meetings and any other locally effective way of communication. 


\subsubsection{Communication during a cyanotoxin incident}

If a cyanobacterial bloom is observed and cyanobacterial toxins are suspected to be present in surface water, the committee or task force should be called together for an emergency meeting to first initiate communication with a smaller group of those directly involved (e.g., drinking-water operators and/ or managers of recreational sites). Coordination by the responsible public authority and the site operator is important to confirm that the resources needed for the response are available and that a quick, accurate, effective and harmonised response will take place once the exposure risk is confirmed.

If monitoring results then show cyanobacteria and/or toxins to be above water quality targets or action thresholds (e.g., WHO guideline values (see Table 5.1) or Alert Levels (see Figure 5.2 and 5.4 - or any values derived nationally)), even after control measures are applied, the committee or task force should verify that communication materials already prepared (see above) are appropriate for the specific situation or adjust them as needed, making sure that the message is consistent across all partners involved in the response. The committee or task force will determine the appropriate content, format and frequency of the risk communication. Public notification regarding restrictions on water use may be required to minimise the potential for exposure. "Do not drink" advisories are recommended only if they are necessary to reduce a relevant public health risk, and this decision is usually the responsibility of the drinking-water system or public health authority. Likewise, "do not swim" advisories should be balanced against the health benefits of outdoor water-related activities.

An example of a communication material is given in Figure 5.7 in section 5.2. Further information materials with more detail should give specific information about the current event, including information about the extent of occurrence in relation to water quality targets or action thresholds, if available, on the species of cyanobacteria and toxin concentrations detected, how humans and animals are affected, when the incident started, who is the responsible agency in-charge of the response, date and specific location of the incident, name and phone number of a contact person, steps taken to respond and mitigate/control the incident, as well as precautionary measures such as avoiding contact with contaminated water, rinsing with clean water after coming in contact, keeping pets or livestock away from the bloom and any other relevant information.

\subsubsection{Communication after a cyanotoxin incident}

Once the bloom is over or under control, the committee or task force should notify the public and other related partners that the incident is resolved and that the water is safe from cyanobacteria and their toxins. The committee or task force could use the same communication outlets contacting the same partners that were notified of the cyanotoxins incident. Communication 
will be trusted best if it includes information about the final decision, control measures applied, monitoring results, future follow-up steps, longerterm prevention approaches and related outreach materials.

\section{I5.7 FOLLOW-UP ASSESSMENT OF INCIDENT MANAGEMENT}

A post-incident comprehensive assessment (Table 15.3) to identify the adequacy of the cyanotoxins incident response and assess the effectiveness of the risk communication activities during and after the incident will improve the basis for next time. A debrief with all the involved agencies (e.g., drinking-water supplies and managers of recreational sites) after the incident helps to identify problems and flaws during the incident and to determine areas that need improvement, as well as those actions that contributed to a successful response and that should be repeated in future cyanotoxins contamination events.

It is also useful for the committee or task force to assess the effectiveness of the risk communication during the incident, for example - in the case of toxins in drinking-water - by conducting a customer survey. This can include questions on how well the type of information provided met information needs and how they learned about the incident. The results of the debrief and customer survey should be used to update or modify the incidence response plan (IRP), if appropriate.

\section{I5.8 PUBLIC PARTICIPATION}

Involving observations of the population using a waterbody in the context of site inspection and when developing a monitoring programme or a Water Safety Plan (WSP) can be highly useful for obtaining information that otherwise might be missed. This may help with focusing attention to high-risk bloom situations as well as practices causing nutrient loads to a waterbody (see section 6.2.2). However, there are numerous situations (including settings with a high level of surveillance) in which the capacity of the responsible authority is not sufficient to ensure that the water does not contain hazardous concentrations of cyanotoxins. This applies particularly for surveillance of waterbodies for recreational use. Monitoring and surveillance at sufficiently tight intervals both in time and in space to ensure capturing high-risk situations may not be feasible, for example, in areas with a large number of waterbodies used for recreation under the responsibility of one public authority. Also, implementing management plans and seeing results may take time. For example, it may take years for an ecosystem to respond to the point where blooms are effectively prevented, and scum situations are 
not always captured by monitoring. Particularly in such situations, involving site users - that is, the general public - in schemes of monitoring and reporting can be important to avoid exposure. This requires giving users the information they need to develop an understanding of risk situations and to be able to make decisions on water use for their own health (see Figure 5.7 in section 5.2.5).

\title{
BOX 15.3: PUBLIC COMMUNICATION THROUGH PUBLIC PARTICIPATION IN DATA COLLECTION - THE CIANO PROJECT IN POTRERO DE GARAY
}

\author{
Raquel del Valle Bazán
}

Los Molinos reservoir in the province of Córdoba, Argentina, is used for many purposes, that is, generation of hydropower, drinking-water production and recreational activities, including extreme sports such as kitesurfing, but also hiking, sports fishing, horseback riding and outdoor festivals. It is a favourite destination both for tourists and for the local population. The largest town on the reservoir shore, Potrero de Garay, has an estimated population of 5000 inhabitants, but during summer, tourism triples this. The town uses drinking-water directly from the reservoir, without prior treatment.

Since approximately 2010, the reservoir has increasingly been afflicted by blooms of Microcystis and Dolichospermum, and citizens of Potrero de Garay are concerned about the quality of the water they use. This gave rise to the citizen science project "Why are our reservoirs green?" abbreviated CIANO project - a collaborate effort between the University of Cordoba and the local lifeguard organisation (GERS) and the Alfonsina Storni School. CIANO targets a combination of education and collecting data by involving citizens in the observation of meteorological conditions, water temperature, Secchi disc, type of turbidity (algal or nonalgal), water colour, water odour, appearance of cyanobacterial blooms and the geographic coordinates. Citizens, in particular students (II and I2 years old) and staff of GERS, are introduced to the project in workshops and are then invited to report their observations in a WhatsApp group (composed of members of the three participating institutions) following a simple form introduced at the workshop (Figure I). The project management processes the data and shares a report on the results of the cyanobacterial monitoring as well cyanobacteria alert levels (Table I). This information is communicated both to government authorities and to private organisations involved in water treatment for the city of Córdoba. 


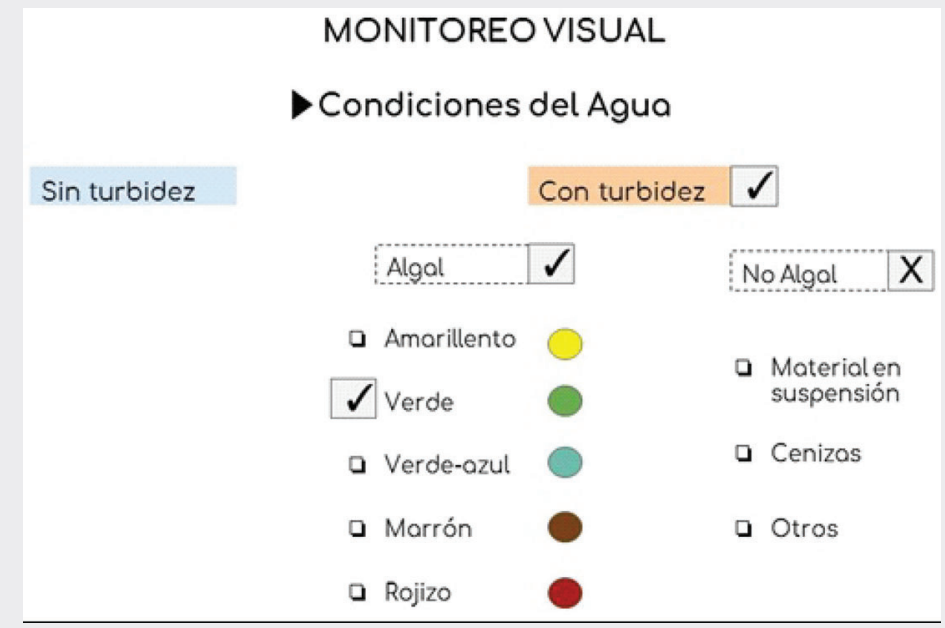

Figure I Reporting form for the "condition of the water" by colour and turbidity (note that "cenizas" means "ashes from forest fires" and "otros" means "others" - i.e., macrophytes).

Table I Example of data collected through the project app and reported to the public and authorities

\begin{tabular}{llccccc}
\hline & \multicolumn{1}{c}{ Site } & $\begin{array}{c}\text { Secchi } \\
\text { depth } \\
(\mathrm{m})\end{array}$ & $\begin{array}{c}\text { Water } \\
\text { temp. } \\
\left({ }^{\circ} \mathrm{C}\right)\end{array}$ & $\begin{array}{c}\text { Air } \\
\text { temp. } \\
\left({ }^{\circ} \mathrm{C}\right)\end{array}$ & $\begin{array}{c}\text { Wind } \\
\text { speed } \\
(\mathrm{km} / \mathrm{h})\end{array}$ & $\begin{array}{c}\text { Cyanobacterial } \\
\text { blooms }\end{array}$ \\
\hline 22 October 2019 & Centro & 2.1 & 17.0 & 19.7 & 25.6 & Absence \\
23 October 2019 & Los Espinillos & 1.5 & 21.0 & 18.8 & 5 & Absence \\
25 October 2019 & Centro & 4.0 & 18.0 & 20.2 & 9.7 & Absence \\
26 October 2019 & Garganta & 6.5 & 18.0 & $\mathrm{~s} / \mathrm{d}$ & $\mathrm{s} / \mathrm{d}$ & Absence \\
31 October 2019 & Presa & 5.0 & 18.0 & 20.5 & 7.2 & Absence \\
3 November 2019 & Los Espinillos & 2.3 & 19.0 & 23.0 & 11.0 & Absence \\
4 November 2019 & Los Espinillos & 3.0 & 19.0 & 21.6 & 19.4 & Absence \\
\hline
\end{tabular}

One of the tools introduced at the workshops is the "cyanosemaphore" poster, provided by the Ministerio de Salud de la Nación (Health Ministry) for dissemination and prevention of exposure in coastal areas of reservoirs, lakes and rivers. It indicates whether or not specific recreational activities are possible or should be avoided (Figure 2). It is also disseminated in hospitals and Primary Health Care Centres. 


\section{Ciano Semáforo}

Prevención de riesgos por contacto con cianobacterias (algas verde-azules) en agua ambiente

No tenga miedo, tenga cuidado

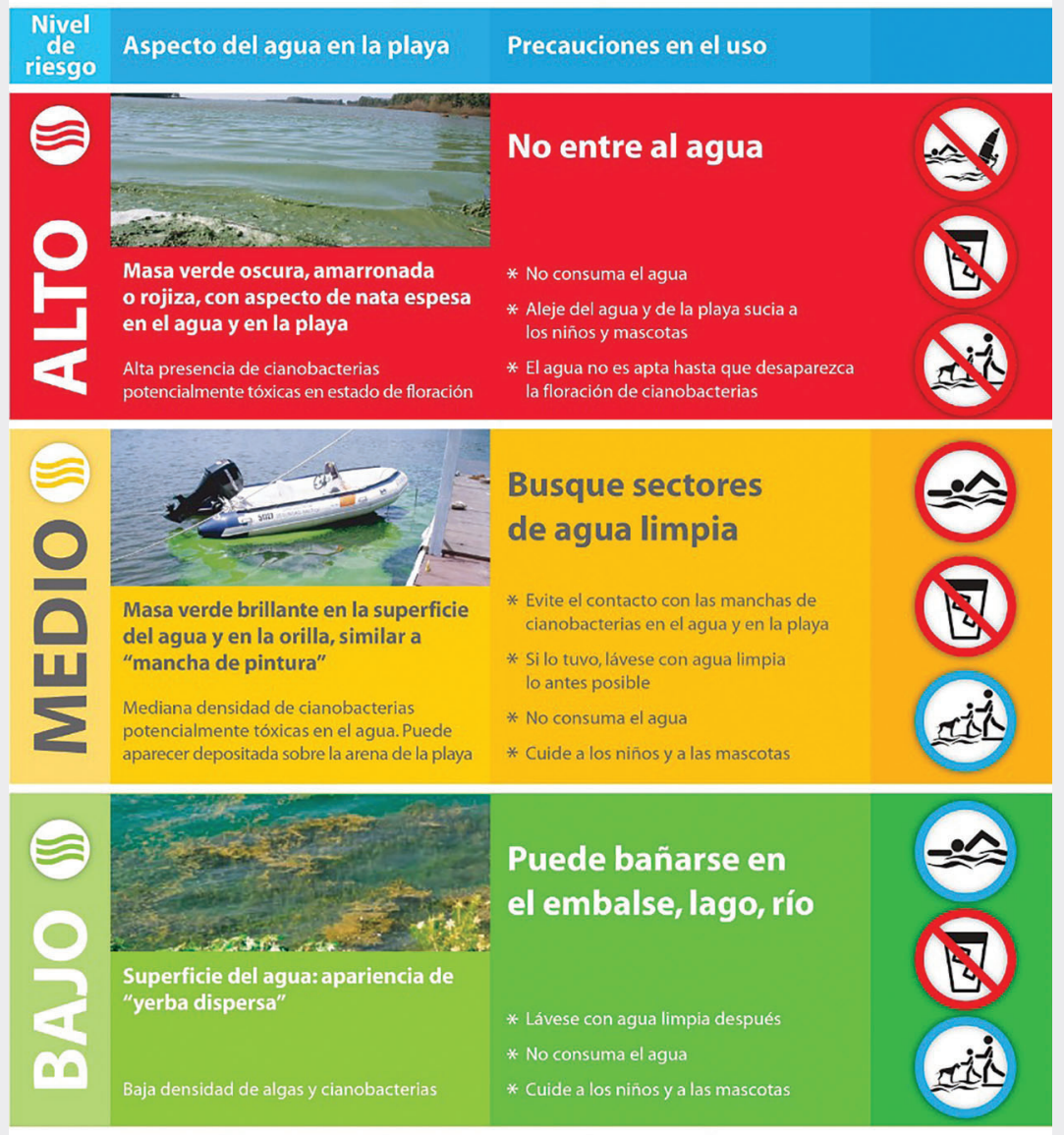

Si siente náuseas, diarrea y cualquier otro sintoma consulte a su médico

ollame las 24 hs. al 0-800-333-0160:Centro Nacional de Intoxicaciones - Hospital "Prof. A. Posadas"

Si su mascota tiene vómitos, diarrea o convulsiones, consulte a su veterinario

Dirección Nacional

de Determinantes de la Salud

e Investigación

\begin{tabular}{l|l} 
Ministerio de \\
Salud
\end{tabular}

Figure 2 "Cyanosemaphore" with three levels of water quality and corresponding advice for water use. Source: http://www.msal.gob.ar/politicassocioambientales/index.php/ciudadanos/folletos-y-afiches 
The students act as multipliers of knowledge in their homes and in the community, particularly for communicating bloom alarms. They exhibited information at their stand at the annual school fair where they handed out a brochure they had developed to explain what cyanobacteria are, how they affect health, what precautions to take, as well as the meaning of the different alert levels of the "cyanosemaphore" (Figure 3).
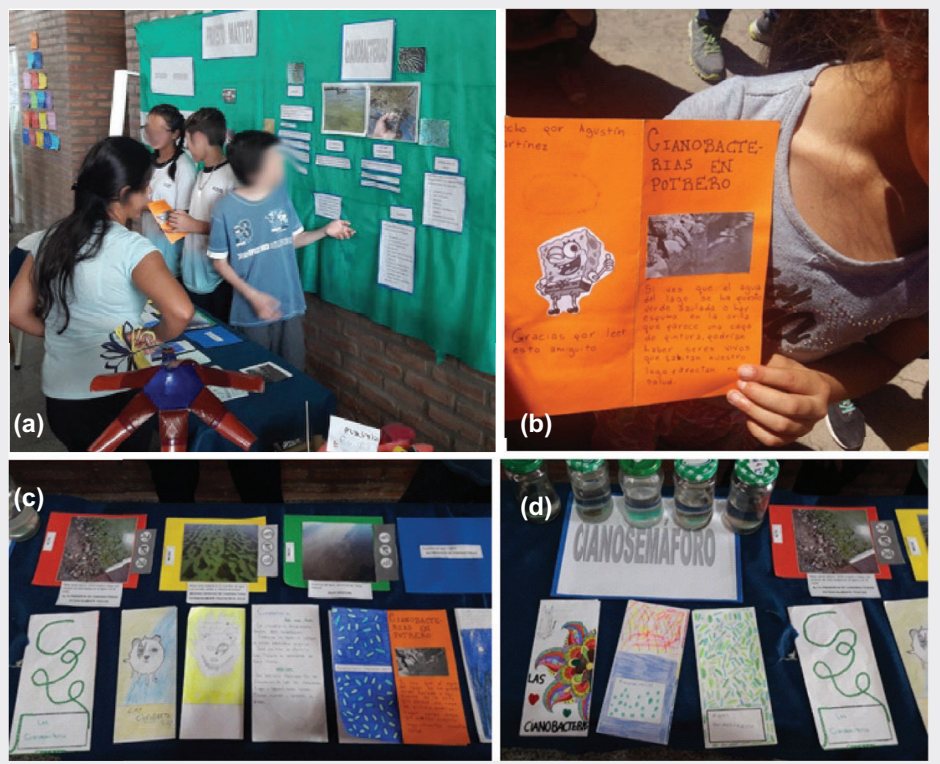

Figure 3 (a) Stand at the annual school fair, (b) brochure by sixth grade students, (c and d) explanation and visualisation of the different alert levels of the "cyanosemaphore".

While the input for water quality monitoring is yet to be evaluated, the first year of the project already achieved a positive impact on awareness of cyanobacterial blooms and their implications for health. Responses and comments of sixth grade students include the following:

Observo como está el agua, si puedo meterme o no. Ahora que lo sabemos puedo tomar precauciones y prevenir a otras personas. Antes, nos metíamos cuando el agua estaba verde (porque no lo sabíamos), ahora no.

I observe how the water is to see how it is, if I can get in or not. Now that we know I can take precautions and prevent others. Before we got in when water was green (because we didn't know better), but not anymore 
Miro el agua, también puedo comunicar a los demás que tengan cuidado para que no se enfermen, puedo ver el estado del agua y me fijo primero si me puedo meter o no. Además, ahora sé que no puedo tomar directamente el agua (aunque no tenga muchas cianobacterias).

I look at the water, and I can also tell others to be careful not to get sick, because I can see the condition of the water, and I first look whether I can get in or not. Also, now I know that I can't drink water directly (even if it does not have many cyanobacteria).

Dependiendo del color del agua, puedo entrar al agua o no. Si está con una coloración verde oscuro no puedo entrar, pero si está claro si puedo hacerlo!

Depending on the color of the water I can get into the water or not. If it is dark green I cannot get in, but it is clear I can.

The example in Box 15.3 shows how a research project uses a citizen science approach involving school children in observations and informing others, while at the same time contributing to the collection of data that will describe the bloom situation in the reservoir. Such public participation can also serve to generate political initiatives and interest in waterbody management towards preventing blooms.

A further aspect of public participation is generating broader support for protection of the waterbody and/or its catchment. The example in Box 15.4 shows how broad involvement of the public served to improve the vegetation cover of a riparian buffer zone and fencing around the reservoir, thus keeping animals out of the water and targeting improved retention of nutrients. Involving citizens develops a sense of ownership and responsibility and thus supports the implementation of use restrictions that might otherwise meet resistance.

\title{
BOX 15.4: RESTORING RIPARIAN AREAS OF PASO SEVERINO RESERVOIR, URUGUAY, WITH CITIZEN'S PARTICIPATION
}

\author{
Rafael Bernardi, Eduardo Andrés, Elisa \\ Dalgalarrondo, Cesar García, Natalia Jara
}

In 2013, the Government of Uruguay issued an action plan to address water quality issues in the Santa Lucía Basin, which provides water to $60 \%$ of the country's population (see Box 7.3 in Chapter 7). One of the measures it stipulates is the establishment of riparian buffer zones with no agricultural activity 
around the main waterbodies of the basin, and the National Direction of Environment (DINAMA) has accordingly initiated and led a programme to manage and restore the buffer zone of Paso Severino, the main reservoir in the basin, in partnership with several institutions: the national water company (OSE), local governments, the ministry of agriculture (MGAP), and the Botanical Garden of Montevideo, among others.

The reservoir has a capacity of $70 \mathrm{M} \mathrm{m}^{3}$ and a perimeter of $\sim 110 \mathrm{~km}$. The riparian land up to the flood level is owned by OSE, but has been traditionally used by local producers that extended the agricultural and livestock use up to the reservoir shore, affecting the water quality. The first measure was to fence the reservoir, restricting access to the shore. This resulted in an initial conflict with local producers which has gradually been solved, although some contentious issues persist. However, the government offers assistance to affected producers, including financial support for installing drinking-water supply for livestock as alternative to direct access to the reservoir.

A key component of the measure was to build a strong participation programme, partnering with the volunteer programme of the ministry of social development (MIDES) and with local schools and institutions, staff associations and local actors. Trees were first provided by national and local governmental nurseries and later from nurseries established by the community with the support of the Small Grant Programme. In total, more than 200 volunteers have participated, many of them attending several days, together with children of several schools of the region and staff from partnering institutions, totalling approximately 1000 working days over a 4-year period.

The programme planted approximately 5000 trees and constructed infrastructure for their protection. It has placed posters with information about the measures implemented and to discourage unauthorised use of the area, and a lookout platform was built together with the community of the nearby town "25 de Mayo".

Native saplings and juvenile trees were planted in the perimeter of the reservoir, with a choice of species and their spatial distribution according to ecological conditions of the sites. Natural regeneration is being monitored. Initial estimates show a survival of over $90 \%$ of individuals planted, although monitoring efforts are still underway, the design of which was developed together with the local community. Also, a partnership was established with the University of the Republic of Uruguay to assess the effects of different natural covers on the retention of nutrient loads to the reservoir. 
The success of the programme up to the end of 2019 has been twofold: one is the active participation and sense of ownership by the local community and volunteers from Montevideo who can now visit their water source and contribute to its restoration. The other is that this active management has prevented lands from being reclaimed for their previous use. Maintaining these two objectives is challenging, but key to ensure the long-term management of this water source.

\section{FURTHER READING}

Bartram J, Corrales L, Davison A, Deere D, Drury D, Gordon B et al. (2009). Water safety plan manual: step-by-step risk management for drinking-water suppliers. Geneva: World Health Organization. Available online at: https://apps. who.int/iris/handle/10665/75141

CDC (2016). Drinking water advisory communication toolbox. Centers for Disease Control and Prevention, Atlanta, GA. Available online at: http://www.cdc. gov/healthywater/emergency/dwa-comm-toolbox/

Chorus, I. (2012). Current approaches to Cyanotoxin risk assessment, risk management and regulations in different countries. Dessau-Roßlau: Federal Environment Agency. Available online at: https://www.umweltbundesamt.de/ sites/default/files/medien/374/publikationen/4390.pdf.

Gianuzzi, L. (2009). Cianobacterias y Cianotoxinas. Identificación, Toxicología, Monitoreo y Evaluación de Riesgo. Moglia S.R.L., Corrientes, Argentina: Instituto Correntino del Agua y Administración de Obras Sanitarias de Corrientes. 237p. Available at: http://www.icaa.gov.ar/2010/gerencias/gest_ ambiental/manualcianobacterias.htm

Health Canada (2012a). Guidelines for Canadian recreational water quality, third edition. Ottawa: Water, Air and Climate Change Bureau, Healthy Environments and Consumer Safety Branch, Health Canada. (Catalogue No H129-15/2012E). Available at: https://www.canada.ca/en/health-canada/services/environmentalworkplace-health/water-quality/recreational-water-water-quality.html

Health Canada (2012b). Guidelines for Canadian drinking water quality: guidance technical document -cyanobacterial toxins. Ottawa: Water, Air and Climate Change Bureau, Healthy Environments and Consumer Safety Branch, Health Canada. Available online at: https://www.canada.ca/en/health-canada/services/publications/healthy-living/guidelines-canadian-drinking-water-quality-guideline-technical-document-cyanobacterial-toxins-document.html

Ministry for the Environment and Ministry of Health (2009). New Zealand guidelines for cyanobacteria in recreational fresh waters - interim guidelines. Prepared for the Ministry for the Environment and the Ministry of Health by SA Wood, DP Hamilton, WJ Paul, KA Safi and WM Williamson. Wellington: Ministry for the Environment. Available online at: https:/www.mfe.govt.nz/ sites/default/files/nz-guidelines-cyanobacteria-recreational-fresh-waters.pdf

Newcombe, G. (ed) (2009). International guidance manual for the management of toxic cyanobacteria: a guide for water utilities. Global Water Research 
Coalition, Unley, SA. Available online at: https://www.waterra.com.au/ cyanobacteria-manual/PDF/GWRCGuidanceManualLevel1.pdf.

Newcombe, G., House, J., Ho, L., Baker, P., and Burch, M. (2010). Managing strategies for cyanobacteria (blue-green algae): a guide for water utilities. Water Quality Research Australia: Research Report 74. Available online at: http://www.waterra.com.au/publications/document-search/?download=106.

New Zealand Ministry of Health (2017). Guidelines for drinking-water quality management for New Zealand, third edition. Wellington: Ministry of Health. Available online at: https://www.health.govt.nz/publication/guidelinesdrinking-water-quality-management-new-zealand; Datasheets for cyanotoxins available online at: https://www.health.govt.nz/system/files/documents/ publications/vol_3_ds_2.4_cyanotoxins_0.doc

Scottish Government Health and Social Care Directorates Blue-Green Algae Working Group (2012). Cyanobacteria (blue-green algae) in inland and inshore waters: assessment and minimization of risks to public health. Available online at: https://www.gov.scot/publications/cyanobacteria-blue-green-algae-inlandinshore-waters-assessment-minimisation-risks-public-health/

UNESCO (2009). Cianobacterias Planctónicas del Uruguay. Manual para la identificación y medidas de gestión. Sylvia Bonilla, (Ed). Documento Técnico PHI. LAC, $N^{\circ} 16.94 p$. Available online at: https://www.academia.edu/32964769/ Cianobacterias_Planct\%C3\%B3nicas_del_Uruguay._Manual_para_la_ identificaci\%C3\%B3n_y_medidas_de_gesti\%C3\%B3n

USEPA (2003). Drinking Water Utility Response Protocol Toolbox (DWRPTB). Office of Water. Available online at: https://www.epa.gov/waterutilityresponse/ drinking-water-and-wastewater-utility-response-protocol-toolbox\#DWRPTB

USEPA (2008). Water security initiative: interim guidance on developing consequence management plans for drinking water utilities. Office of Water. EPA 817-R-08-001. Available online at: https://www.epa.gov/sites/ production/files/2015-06/documents/wsi_interim_guidance_on_developing consequence_management_plans_for_drinking_water_utilities.pdf

USEPA (2016) Drinking water cyanotoxin risk communication toolbox - templates. Available online at: https://www.epa.gov/ground-water-and-drinking-water/ drinking-water-cyanotoxin-risk-communication-toolbox-templates.

USEPA (2017). Sampling guidance for unknown contaminants in drinking water. Office of Water. EPA-817-R-08-003. Available online at: https://www.epa. gov/sites/production/files/2017-02/documents/sampling_guidance_for_ unknown_contaminants_in_drinking_water_02152017_final.pdf.

WHO (2003). Guidelines for safe recreational water environments: Coastal and fresh waters (Vol. 1). Geneva: World Health Organization. Available online at: https://apps.who.int/iris/handle/10665/42591

WHO (2012). Water safety planning for small community water supplies: step-by-step risk management guidance for drinking-water supplies in small communities. Geneva: World Health Organization. Available online at: https://apps.who.int/iris/handle/10665/75145

WHO (2017). Guidelines for drinking-water quality, fourth edition, incorporating the 1st addendum. Geneva: World Health Organization. Available online at: https://www.who.int/publications/i/item/9789241549950 